\title{
EFFECT OF PREDNISOLONE ON THE TOXICITY OF BORDETELLA PERTUSSIS FOR MICE
}

\author{
R. PARTON
}

\section{Department of Microbiology, University of Glasgow, Alexander Stone Building, Garscube Estate, Bearsden, Glasgow G61 1QH}

\begin{abstract}
Summary. Prednisolone, given orally or intraperitoneally before challenge, protected mice against the lethal effect of a crude cell extract of Bordetella pertussis containing heat-labile toxin (HLT) as the major toxic component. Prednisolone did not diminish the lethal toxicity of heated $B$. pertussis cell suspensions containing pertussis toxin and endotoxin but devoid of HLT. This suggests that the protective effect of the steroid was directed against the HLT. When live bacteria were injected intraperitoneally, prednisolone showed a protective effect against the initial toxaemia. By day 7 , however, the protection was no longer evident and the steroid promoted the survival of the organisms within the peritoneal cavity. These findings are discussed in the light of reports of the beneficial effects of corticosteroids in the treatment of whooping cough and in relation to a possible role for HLT in the pathogenesis of the disease.
\end{abstract}

\section{INTRODUCTION}

Bordetella pertussis produces three distinct toxins,- pertussis toxin (or pertussigen), a heat-labile dermonecrotising toxin (HLT) and endotoxin-and a number of other, less well characterised toxic substances (Wardlaw and Parton, 1982 and 1983). Despite much recent investigation and speculation, the role of these toxins in the pathogenesis of whooping cough remains obscure. Pittman (1979) has suggested that the harmful effects of the disease, including the paroxysmal cough, are caused by pertussis toxin which diffuses from the site of infection and acts systemically to cause a variety of pathophysiological changes. These effects on the host persist long after the organisms have been eliminated. However, the primary stimulus to coughing may be local irritation due to local inflammatory disease and locally-acting toxins (Olson, 1975).

Once the paroxysmal stage has been reached, it is generally considered that little can be done to modify the course of the disease (Miller and Fletcher, 1976). Antibiotics may accelerate the elimination of infection, but do not halt the paroxysmal coughing. However, several reports have suggested that corticosteroids should be considered for the treatment of severe pertussis. Zoumboulakis et al. (1973) showed that hydrocortisone given intramuscularly over a period of 7-8 days significantly reduced the frequency of coughing, whooping and vomiting and shortened the duration of the 
illness, especially in infants under one year old. Both control and steroid-treated groups received erythromycin. The earlier work of Dayal et al. (1969) had also suggested that prednisolone with tetracycline was beneficial in the treatment of pertussis. More recently, Barrie (1982) stressed that the paroxysmal cough was suppressed by steroids and cited three cases in 8-13-week-old infants in which oral prednisolone dramatically reduced the severity and number of coughing spasms. Further support for this form of treatment was provided by Dianese (1982).

A major obstacle in pertussis research is the lack of a satisfactory animal model for the paroxysmal coughing syndrome in man. However, each of the three toxins is lethal for mice when injected intraperitoneally and they can be differentiated on the basis of heat stability and, to some extent, on the time taken to cause death (Ishida, 1968). The object of the work reported here was to explore the possible effect of prednisolone on the toxicity of $B$. pertussis cells and cell extracts in mice.

\section{Materials AND METHODS}

Strains. B. pertussis strain 18334 , a vaccine strain, was obtained originally from Connaught Laboratories Ltd, Toronto. Strain 18-323, a challenge strain used for the intracerebral mouse protection test, was obtained from Dr F. Sheffield, National Institute for Biological Standards and Control, Holly Hill, Hampstead, London NW3 6RB.

Cell extract was prepared from $B$. pertussis strain 18334 grown in modified Hornibrook medium (Wardlaw et al., 1976) for $48 \mathrm{~h}$ at $37^{\circ} \mathrm{C}$, as described previously (Idigbe et al., 1981). Cultures were harvested by centrifugation at $10000 \mathrm{~g}$ for $30 \mathrm{~min}$ at $4^{\circ} \mathrm{C}$. Packed cells were resuspended in saline ( $\mathrm{NaCl} 0.85 \% \mathrm{w} / \mathrm{v})$ and, after freezing, were disrupted by three passages through an X-press (Life Sciences Laboratories Ltd, Sarum Road, Luton). After thawing, the suspension was centrifuged at $100000 \mathrm{~g}$ for $30 \mathrm{~min}$ at $4{ }^{\circ} \mathrm{C}$. The supernate of the cell lysate (cell extract) was distributed in small amounts and stored at $-20^{\circ} \mathrm{C}$. For use, it was thawed and diluted in Dulbecco A phosphate-buffered saline (Oxoid) (PBS).

Heated cell suspensions were also prepared from B. pertussis strain 18334 grown and harvested as described. Cells were resuspended in PBS and heated at $56^{\circ} \mathrm{C}$ for $30 \mathrm{~min}$. Thiomersal $(\mathrm{BDH})$ was added as a preservative at a final concentration of $0.1 \mathrm{mg} / \mathrm{ml}$ and the suspension was freeze-dried in small amounts. It was reconstituted in sterile distilled water immediately before use. The $100^{\circ} \mathrm{C}$-suspension was prepared from a batch of the $56^{\circ} \mathrm{C}$-heated suspension by steaming for $1 \mathrm{~h}$.

Live challenge suspensions were prepared from B. pertussis strain 18-323 grown on Bordet-Gengou agar (Gibco Biocult Diagnostics Ltd, Paisley, Scotland), supplemented with sterile defibrinated horse blood (Gibco) $20 \% \mathrm{v} / \mathrm{v}$, for $48 \mathrm{~h}$ at $37^{\circ} \mathrm{C}$. Growth from the plates was resuspended in sterile Casamino acids solution containing Casamino acids (Difco technical) $10 \mathrm{~g} / \mathrm{L}, \mathrm{NaCl} 5 \mathrm{~g} / \mathrm{L}, \mathrm{MgCl}_{2} \cdot 6 \mathrm{H}_{2} \mathrm{O} 0 \cdot 1 \mathrm{~g} / \mathrm{L}$ and $\mathrm{CaCl}_{2} 0 \cdot 016 \mathrm{~g} / \mathrm{L}, p \mathrm{H} 7 \cdot 1$. The concentration of the cells was standardised against the WHO 5th International reference preparation of opacity (Perkins et al., 1973) to give a notional value of $10^{10}$ cells $/ \mathrm{ml}$.

Lethality titrations were done in 3-4-week-old male HaM/ICR mice (Charles River, UK Ltd, Manston Road, Margate, Kent CT9 4LT). Groups of mice of similar weight were given intraperitoneal (ip) injections of graded doses of the $B$. pertussis preparations. Deaths were recorded daily.

Recovery of $B$. pertussis from the peritoneal cavity. Mice surviving ip challenge with live cells were killed by cervical dislocation. The skin was stripped from the abdomen and $2 \mathrm{ml}$ of sterile Casamino acids solution was injected into the peritoneal cavity along the mid-anterior line. After massage of the abdomen for $30 \mathrm{~s}, 0.5 \mathrm{ml}$ was withdrawn from the pocket of fluid formed at the flank and, of this, $0.1 \mathrm{ml}$ was plated on to Bordet-Gengou agar. Colonies were counted after incubation for 4-5 days at $37^{\circ} \mathrm{C}$. The identity of the B. pertussis colonies was confirmed by slide agglutination with rabbit antipertussis serum (obtained from C.R. Manclark, Division of Biologics Standards, NIH, Bethesda, MD, USA).

Prednisolone treatment. For oral administration, prednisolone-21-sodium succinate (Sigma) 
was dissolved in tap water and offered to the mice ad libitum in the usual water bottle. The solution was changed daily. For ip injection, the steroid was dissolved in PBS.

Protein estimations on the cell extract and cell suspensions were done by the method of Herbert et al. (1971) with bovine serum albumin as a standard.

Statistical methods. LD50 values and 95\% confidence limits were calculated by the probit method (Finney, 1964). For determining the significance of differences between proportion data from the challenge experiments, $2 \times 2$ contingency tables (Finney et al., 1963) were used.

\section{RESULTS}

\section{Effect of prednisolone on the lethal toxicity for mice of $B$. pertussis cell extract}

Graded doses of a crude cell extract of B.pertussis, injected ip into 3-week-old mice, were rapidly lethal. Most deaths occurred within one or two days of challenge and usually there were no further deaths after day 3 (table I). By heating the cell extract to $56^{\circ} \mathrm{C}$ for $30 \mathrm{~min}$, toxicity was greatly reduced; LD50 values of unheated and heated samples were calculated to be 1.34 and $>240 \mu \mathrm{g}$ of cell-extract protein per mouse respectively. In view of the rapid killing (Ishida, 1968) and the reduction of the toxicity by mild heat treatment (Munoz, 1971), deaths in this assay were assumed to be due primarily to the heat-labile toxin (HLT) of B. pertussis.

Mice given prednisolone sodium succinate $(150 \mu \mathrm{g} / \mathrm{ml})$ in their drinking water from day 2 before challenge to day 4 after challenge, were afforded significant protection against the toxin (table I). At day 3, the LD50 value for the cell extract was $3.0 \mu \mathrm{g}$ protein per mouse. A few more deaths occurred up to day 7 , but the protective effect was still significant. No deaths occurred in unchallenged animals receiving prednisolone, but all groups of animals given the steroid failed to gain weight normally.

In the above experiment, the mice received a high dose of prednisolone in their drinking water, equivalent to approximately $0.7 \mathrm{mg}$ of steroid/mouse/day, or $50 \mathrm{mg}$

TABLE I

Effect of oral prednisolone on the lethal toxicity for mice of B. pertussis cell extract

\begin{tabular}{|c|c|c|c|c|c|c|}
\hline \multirow[b]{2}{*}{ Treatment } & \multirow{2}{*}{$\begin{array}{c}\text { Challenge dose } \\
\text { ( } \mu \text { g protein/mouse) }\end{array}$} & \multicolumn{3}{|c|}{$\begin{array}{l}\text { Number of } \\
\text { survivors } \\
\text { on day }\end{array}$} & \multicolumn{2}{|c|}{$\begin{array}{c}\text { LD50 ( } \mu \text { g protein/mouse) } \\
\text { on day }\end{array}$} \\
\hline & & 0 & 3 & 7 & 3 & 7 \\
\hline & 6 & 20 & 0 & 0 & $1 \cdot 34$ & $1 \cdot 34$ \\
\hline Water only & 3 & 20 & 2 & 2 & $(1 \cdot 67,1 \cdot 09) \dagger$ & $(1 \cdot 67,1 \cdot 09)$ \\
\hline (Controls) & $1 \cdot 5$ & 20 & 6 & 6 & & \\
\hline Prednisolone* & 6 & 20 & 1 & 1 & $3 \cdot 0$ & $2 \cdot 72$ \\
\hline in drinking water & 3 & 20 & 10 & 8 & $(3 \cdot 58,2 \cdot 52)$ & $(3 \cdot 28,2 \cdot 24)$ \\
\hline from day -2 to +4 & $1 \cdot 5$ & 20 & 19 & 18 & & \\
\hline
\end{tabular}

* The average daiy intake per mouse at the time of challenge was $0.7 \mathrm{mg}$ prednisolone $/ \mathrm{mouse} /$ day or 50 $\mathrm{mg}$ prednisolone $/ \mathrm{kg}$ body weight/day.

+ Figures in brackets are the $95 \%$ confidence limits. 
steroid/kg body $\mathrm{wt} /$ day over a 7-day period. However, these daily intakes are calculated from the consumption of drinking water up to the time of challenge, and, after challenge, sick animals drank less than less severely affected animals. In groups of mice given graded doses of prednisolone from day 2 before challenge to day 4 after challenge, doses of $>3.75 \mathrm{mg} / \mathrm{kg}$ body wt/day still gave significant protection (fig. 1).

Prednisolone also protected mice against HLT challenge when given by the ip route. Fig. 2 shows the effect of two doses ( $1.4 \mathrm{mg} /$ mouse) of prednisolone given ip either $24 \mathrm{~h}$ and $3 \mathrm{~h}$ before challenge or $3 \mathrm{~h}$ and $24 \mathrm{~h}$ after challenge compared with control animals given diluent only. In this experiment, the challenge dose was slightly less toxic than in previous experiments and late deaths occurred in all three groups. Prednisolone was highly protective at day 3 and day 7 if given before challenge, but less effective if given after challenge. In the latter groups, protection was highly significant at day 3 but not significant at day 7 , with 9 out of 20 animals surviving compared with 5 out of 20 in in the control group.

\section{Effect of oral prednisolone on the lethal toxicity for mice of heated cell suspensions}

B. pertussis cell suspensions were heated either to $56^{\circ} \mathrm{C}$ for $30 \mathrm{~min}$ or to $100^{\circ} \mathrm{C}$ for 1h. The former treatment destroys HLT but leaves active pertussis toxin and endotoxin, whereas the latter treatment allows only endotoxin to persist, because pertussis toxin is destroyed by heating to $80^{\circ} \mathrm{C}$ for $30 \mathrm{~min}$ (Wardlaw and Parton, 1982). When these suspensions were used to challenge prednisolone-treated and normal mice,

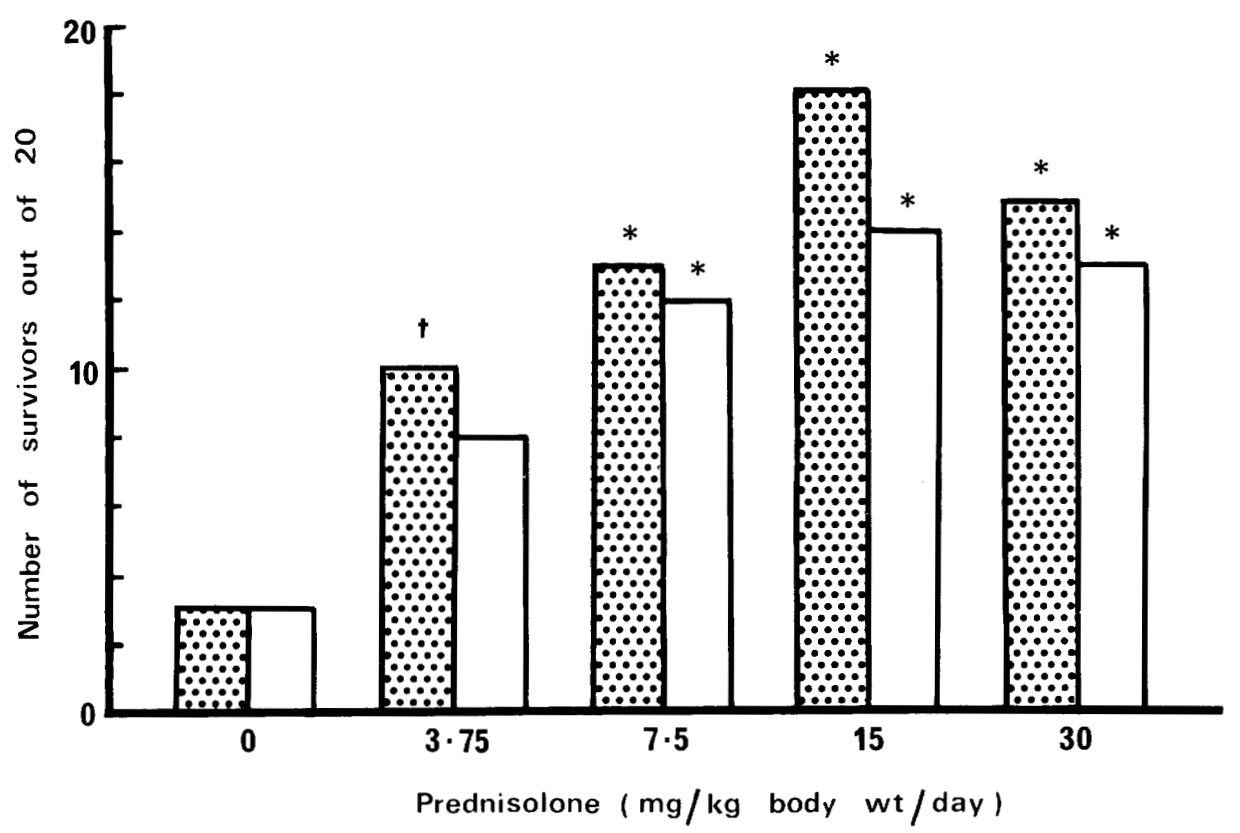

Fig. 1--Effect of graded doses of oral prednisolone on the lethal toxicity for mice of $B$. pertussis cell extract. All animals were challenged with $3 \mu \mathrm{g}$ of cell-extract protein. Shaded area represents survivors on day 3 , unshaded area represents survivors on day $7 ;^{*}=$ highly significant $(p \leqslant 1 \%), \dagger=$ significant $(p \leqslant 5 \%)$ difference from corresponding group of animals receiving no steroid. 


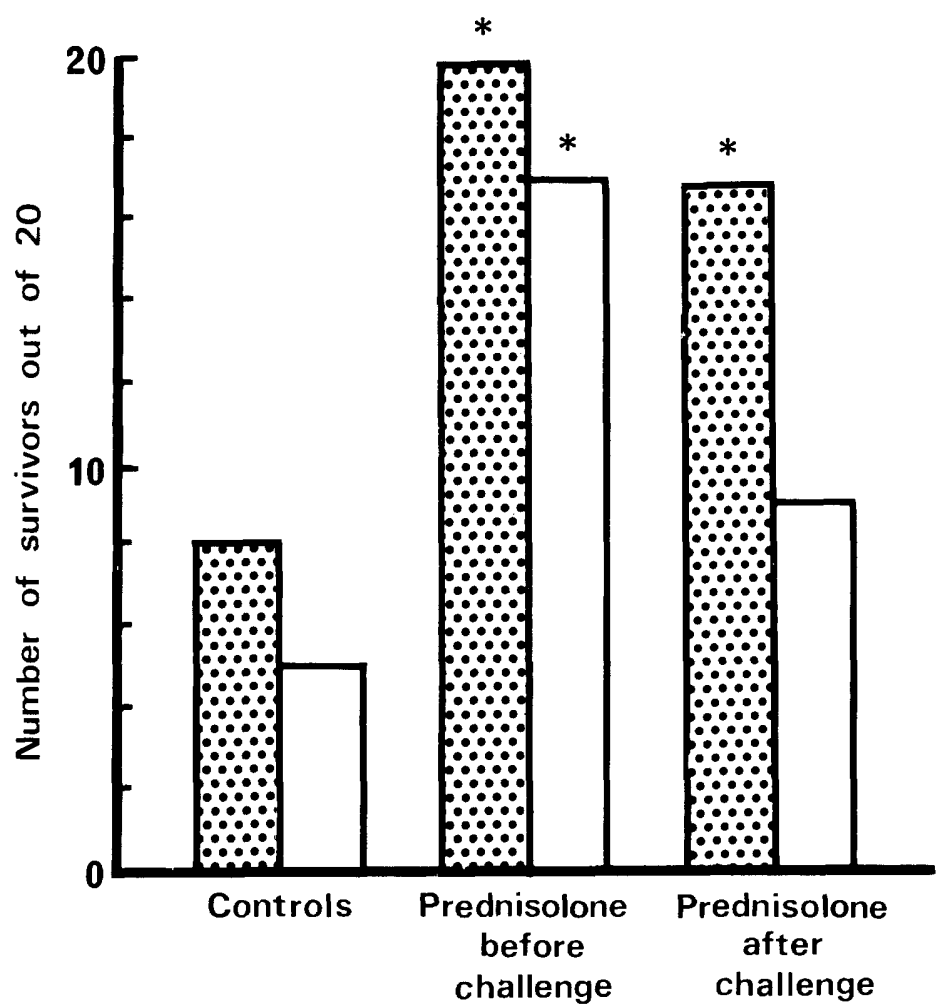

FIG. 2-Effect of prednisolone given ip before or after challenge with B. pertussis cell extract. Prednisolone $(1.4 \mathrm{mg} / \mathrm{mouse}$ ) was given $24 \mathrm{~h}$ and $3 \mathrm{~h}$ before challenge or $3 \mathrm{~h}$ and $24 \mathrm{~h}$ after challenge with $3 \mu \mathrm{g}$ of cell-extract protein. Shaded area represents survivors on day 3 , unshaded area represents survivors on day 7 ; control mice received $0.5 \mathrm{ml}$ of PBS $24 \mathrm{~h}$ and $3 \mathrm{~h}$ before challenge; ${ }^{*}=$ highly significant $(\mathrm{p} \leqslant 1 \%)$ difference from corresponding group of control animals.

no protective effect was seen in the steroid-treated groups (table II). In all groups, most of the deaths had occurred by day 3 , which is characteristic of deaths due to endotoxin rather than to pertussigen (Ishida, 1968); only a few deaths occurred between day 3 and day 7 . The boiled cell suspension was less toxic than the suspension that had been heated to $56^{\circ} \mathrm{C}$, but the suspensions were prepared and tested separately. Challenge with the cell suspension that had been heated to $56^{\circ} \mathrm{C}$ produced no significant difference in toxicity in the control animals and the group treated with steroid. With the boiled suspension, however, the mice treated with prednisolone were almost twice as sensitive to the challenge. No deaths were seen in unchallenged animals given water or steroid for the duration of the experiment.

Effect of oral prednisolone on the lethal toxicity for mice of live B. pertussis given by the ip route

When mice were challenged ip with live cells of $B$. pertussis strain 18323 , those treated with prednisolone were afforded significant protection at day 3 (table III). By day 7 , however, many more deaths had occurred in the groups treated with steroid and the protective effect was no longer evident. 
TABLE II

Effect of oral prednisolone on the lethal toxicity for mice of heated B. pertussis cell suspensions

\begin{tabular}{|c|c|c|c|c|c|c|c|}
\hline \multirow[b]{2}{*}{ Treatment } & \multirow[b]{2}{*}{ Challenge } & \multirow{2}{*}{$\begin{array}{l}\text { Challenge } \\
\text { dose }(\mu \mathrm{g} \\
\text { protein/ } \\
\text { mouse })\end{array}$} & \multicolumn{3}{|c|}{$\begin{array}{l}\text { Number of survivors } \\
\text { on day }\end{array}$} & \multicolumn{2}{|c|}{ LD50 ( $\mu$ g protein/mouse) on day } \\
\hline & & & 0 & 3 & 7 & 3 & 7 \\
\hline & \multirow{6}{*}{$\begin{array}{l}\text { Cell suspension } \\
\text { heated to } 56^{\circ} \mathrm{C} \\
\text { for } 30 \mathrm{~min}\end{array}$} & 675 & 10 & 1 & 0 & & \\
\hline Water only & & 337 & 10 & 7 & 7 & 346 & 265 \\
\hline (Controls) & & 169 & 10 & 9 & 8 & $(454,254) \dagger$ & $(316,223)$ \\
\hline Prednisolone* & & 675 & 10 & 1 & 1 & & \\
\hline in drinking water & & 337 & 10 & 8 & 8 & 389 & 368 \\
\hline \multirow[t]{2}{*}{ from day -2 to +7} & & 169 & 10 & 9 & 8 & $(524,292)$ & $(514,263)$ \\
\hline & \multirow{6}{*}{$\begin{array}{l}\text { Cell suspension } \\
\text { heated to } \\
100^{\circ} \mathrm{C} \text { for } \mathrm{lh}\end{array}$} & 2700 & 10 & 5 & 5 & 2297 & 2225 \\
\hline Water only & & 1350 & 10 & 7 & 6 & $(3024,1744)$ & $(2969,1668)$ \\
\hline (Controls) & & 675 & 10 & 10 & 10 & & \\
\hline Prednisolone* & & 2700 & 10 & 2 & 2 & & \\
\hline in drinking water & & 1350 & 10 & 3 & 3 & 1323 & 1323 \\
\hline from day -2 to +7 & & 675 & 10 & 9 & 9 & $(1846,947)$ & $(1846,947)$ \\
\hline
\end{tabular}

* Dosage as in table I.

$\dagger$ Figures in brackets are the $95 \%$ confidence limits. 
TABLE III

Effect of oral prednisolone on the lethal toxicity for mice of live B. pertussis given by the ip route

\begin{tabular}{|c|c|c|c|c|c|c|}
\hline \multirow[b]{2}{*}{ Treatment } & \multirow{2}{*}{$\begin{array}{c}\text { Challenge dose } \\
\text { (number of organisms, } \\
10^{9} / \text { mouse) }\end{array}$} & \multicolumn{3}{|c|}{$\begin{array}{c}\text { Number of survivors } \\
\text { on day }\end{array}$} & \multicolumn{2}{|c|}{$\begin{array}{l}\text { LD50 (number of } \\
\text { organisms, } 10^{9} \text { ) } \\
\text { on day }\end{array}$} \\
\hline & & 0 & 3 & 7 & 3 & 7 \\
\hline $\begin{array}{l}\text { Water only } \\
\text { (Controls) }\end{array}$ & $\left\{\begin{array}{l}5 \\
2 \cdot 5 \\
1 \cdot 25\end{array}\right.$ & $\begin{array}{l}10 \\
10 \\
10\end{array}$ & $\begin{array}{l}0 \\
6 \\
9\end{array}$ & $\begin{array}{l}0 \\
4 \\
9\end{array}$ & $\begin{array}{c}2 \cdot 04 \\
(2 \cdot 45,1 \cdot 7) \dagger\end{array}$ & $\begin{array}{c}1 \cdot 95 \\
(2 \cdot 4,1 \cdot 58)\end{array}$ \\
\hline $\begin{array}{l}\text { Prednisolone* } \\
\text { in drinking water } \\
\text { from day }-2 \text { to }+7\end{array}$ & $\left\{\begin{array}{l}5 \\
2 \cdot 5 \\
1 \cdot 25\end{array}\right.$ & $\begin{array}{l}10 \\
10 \\
10\end{array}$ & $\begin{array}{r}3 \\
10 \\
10\end{array}$ & $\begin{array}{l}1 \\
5 \\
8\end{array}$ & $\begin{array}{c}5 \cdot 13 \\
(6 \cdot 72,3 \cdot 9)\end{array}$ & $\begin{array}{c}2 \cdot 29 \\
(3 \cdot 21,1 \cdot 63)\end{array}$ \\
\hline
\end{tabular}

* Dosage as in table I.

$\dagger$ Figures in brackets are the $95 \%$ confidence limits.

In a further experiment, peritoneal washings were obtained from surviving animals at day 7 to determine if steroid treatment allowed survival or multiplication of $B$. pertussis in the mouse peritoneal cavity. The results are shown in table IV. With this challenge, over $50 \%$ of the animals in each group survived to day 7 . Again, more prednisolone-treated mice than controls were alive on day 3 , but by day 7 the number of survivors in each group was similar. When counts were made on Bordet-Gengou medium from samples of peritoneal wash fluid, B. pertussis could be recovered from most of the animals. With the higher dose of prednisolone, a large number of organisms was isolated from each of the survivors. Few, if any, colonies were obtained from control mice and the lower dose of prednisolone gave an intermediate result.

\section{TABLE IV}

Effect of oral prednisolone on the lethal toxicity for mice and survival of live B. pertussis $\dagger$ injected ip

\begin{tabular}{|c|c|c|c|c|}
\hline \multirow[b]{2}{*}{ Treatment } & \multicolumn{3}{|c|}{$\begin{array}{l}\text { Number of } \\
\text { survivors on day }\end{array}$} & \multirow{2}{*}{$\begin{array}{l}\text { Median number of cfu recovered } \\
\text { per } 0 \cdot 1 \mathrm{ml} \text { of peritoneal wash fluid }\end{array}$} \\
\hline & 0 & 3 & 7 & \\
\hline $\begin{array}{l}\text { Water only } \\
\text { (Control) }\end{array}$ & 15 & 11 & 10 & 3 \\
\hline $\begin{array}{l}\text { Prednisolone* } \\
5 \mathrm{mg} / \mathrm{kg} \text { body } \mathrm{wt} / \text { day }\end{array}$ & 15 & 13 & 11 & 55 \\
\hline $\begin{array}{l}\text { Prednisolone* } \\
50 \mathrm{mg} / \mathrm{kg} \text { body } \mathrm{wt} / \text { day }\end{array}$ & 15 & 15 & 9 & $>200$ \\
\hline
\end{tabular}

* Given in drinking water from day -2 to +7 . Dosage calculated from the water consumption up to the time of challenge.

$\dagger$ Challenge dose was $c .2 .5 \times 10^{9} \mathrm{cfu}$. 


\section{Discussion}

Glucocorticoids are valuable in the treatment of many diseases in which immunological or inflammatory activity contributes to the pathology, although they can also have undesirable effects such as lowering resistance to infection (Kass and Finland, 1958; Baxter and Rousseau, 1979). Their reported beneficial effects in the treatment of whooping cough (Zoumboulakis et al., 1973; Barrie, 1982) prompted the present investigation into the effect of prednisolone on the various toxic activities of $B$. pertussis for mice.

The paroxysmal coughing stage of pertussis starts at approximately the same time as the pathogen is being eliminated from the host (Pittman, 1970). Thus, there is strong evidence that a long-acting toxin contributes to the harmful effects of the disease. Pittman (1979) suggested that pertussis toxin is the bacterial component responsible. However, it seems likely that more than one component of the organism is necessary for the pertussis syndrome since other Bordetella species, which lack pertussis toxin, can occasionally give rise to a paroxysmal cough, although usually in a mild form. Moreover, the cough may be re-activated by succeeding and unrelated infections (Olson, 1975). Thus, the primary stimulus to coughing may be local irritation but the special features of the paroxysmal stage may only occur when pertussis toxin is also present.

The major toxin of B.pertussis, at least for mice, is the heat-labile toxin (HLT). This can be seen from tables II and III which show that the lowest dose of cells heated to $56^{\circ} \mathrm{C}$ killed only a small proportion of normal mice, whereas the highest dose of live cells, which contained fewer cells, killed all the normal mice. HLT causes inflammation and necrosis when injected into the skin of laboratory animals (Munoz, 1971) and could, therefore, be the primary stimulus to coughing. A role for endotoxin, however, should not be disregarded. It should be noted that the other Bordetella species also contain endotoxin and HLT (Munoz, 1971) and that B. bronchiseptica causes kennel cough in dogs (Thompson et al., 1976).

In the present investigation, prednisolone, given orally or ip before challenge, was found to protect mice against the lethal effect of HLT. Although this does not prove that the beneficial effects of glucocorticoids on whooping cough are due to counteraction of the activities of HLT, the idea does merit consideration. If the local inflammatory effects of HLT on the respiratory tract were inhibited, then the primary stimulus to coughing might be removed. It is of interest to note that prednisolone prevents the dermonecrotising, as well as the lethal, effects of HLT (unpublished observation).

Oral prednisolone did not appear to have any inhibitory effects on the lethal toxicity of cell suspensions of $B$. pertussis heated to $56^{\circ} \mathrm{C}$, a temperature at which activities of both pertussigen and endotoxin are retained. With large doses of boiled cell suspension, where toxicity is presumed to be due to the endotoxin content, the mice treated with prednisolone were more sensitive to the challenge. These findings contrast with those of other workers who have shown that prior administration of glucocorticoids protects mice against challenge with pertussis vaccine (Kind, 1953) or with endotoxin from a variety of gram-negative species (Kass and Finland, 1958). Kind (1953) reported that cortisone protected mice from toxic death following ip injection of a phenol-preserved pertussis vaccine that was presumably devoid of HLT. The details 
of these experiments are not clear, but it appears that $1 \mathrm{mg}$ of cortisone was given intramuscularly $18 \mathrm{~h}$ before challenge and deaths were recorded at $24 \mathrm{~h}$.

The reasons for these discrepancies are not known, but may be related to the use of different strains of mice which could differ in their sensitivity to endotoxin (Sultzer, 1972), the period of observation after challenge and differences in glucocorticoid administration. At the doses of steroid used in the present work, mice were already showing inhibition of the normal rate of weight gain at the time of challenge, resulting, no doubt, from a variety of profound changes in their metabolism (Baxter and Rousseau, 1979).

Although corticosteroids may, in some cases, protect mice against the lethal effects of lipopolysaccharide endotoxins, they do not appear to protect against death due to a number of bacterial protein toxins, including those from Corynebacterium diphtheriae and Clostridium perfringens (Kass and Finland, 1958) which are dermonecrotising. The effect of prednisolone on $B$. pertussis HLT may therefore be unusual and may reflect a different, as yet undefined, mode of action of the toxin.

High doses of live $B$. pertussis injected ip into mice killed the animals rapidly, usually in 1-3 days. Since there is no evidence of bacterial multiplication in the peritoneum, death is thought to be due to the toxin content of the inoculum (Pittman, 1970). In the present study, oral prednisolone gave significant protection to mice up to 3 days after challenge, but thereafter, the protection disappeared. Possibly, the steroid allowed the survival or multiplication of the organisms within the peritoneal cavity by interfering with the normal clearance mechanisms (Fauci, 1979) which, in turn, would increase the toxic burden on the host. Iida et al. (1963) have shown that corticosteroids markedly potentiate infection of mice given virulent, or even avirulent, $B$. pertussis intranasally.

In whooping cough, the infection is being eliminated naturally at around the time that treatment usually starts. Where steroids have been used (Dayal et al., 1969; Zoumboulakis et al., 1973; Barrie, 1982; Dianese, 1982) the children were also given antibiotics, thus making it unlikely that the infection would be prolonged or re-activated. In some infections, however, large doses of corticosteroids may so depress host resistance that the efficacy of antibiotics is limited (Kass and Finland, 1958).

Further investigation of prednisolone and related compounds on the various toxic and pathophysiological activities of $B$. pertussis in laboratory animals may yield further insights into the mechanisms of pathogenesis of whooping cough. For this work, purified toxins would be highly desirable.

I thank Professor A. C. Wardlaw for his advice and encouragement throughout this work, Dr B. Furman for helpful comments and Mrs Elizabeth Berry for skilled technical assistance.

\section{REFERENCES}

Barrie H 1982 Treatment of whooping cough. Lancet 2:830-831.

Baxter J D, Rousseau G G 1979 Glucocorticoid hormone action: an overview. Monographs on Endocrinology 12:1-24.

Dayal R S, Atal P R, Kumar Y 1969 A comparative study of different culture techniques and therapeutic efficacy of newer antibiotics in pertussis. Indian Journal of Medical Sciences 23:421-427.

Dianese G 1982 Treatment of whooping cough: Lancet 2:1224.

Fauci A S 1979 Immunosuppressive and anti-inflammatory effects of glucocorticoids. Monographs on Endocrinology 12:449-465. 
Finney D J 1964 Statistical method in biological assay, 2nd edn. Griffin, London.

Finney D J, Latscha R, Bennett B M, Hsu P 1963 Tables for testing significance in a $2 \times 2$ contingency table. Cambridge University Press.

Hierbert D, Phipps P J, Strange R E 1971 Chemical analysis of microbial cells. In: Norris J R, Ribbons D W (eds) Methods in microbiology, vol. 5B. Academic Press, London, pp 209-344.

Idigbe E O, Parton R, Wardlaw A C 1981 Rapidity of antigenic modulation of Bordetella pertussis in modified Hornibrook medium. Journal of Medical Microbiology 14:409-418.

Iida T, Kunitani A, Komase Y, Yamamoto A 1963 Studies on experimental infection with Bordetella pertussis. Effects of cortisone on the infection and immunity in mice. Japanese Journal of Experimental Medicine 33:283-295.

Ishida S 1968 Characterization of the body weight-decreasing toxicities in mice by the lymphocytosis-promoting factor and the heat-labile toxin of B. pertussis and endotoxin. Japanese Journal of Medical Science and Biology 21:115-135.

Kass E H, Finland M 1958 Corticosteroids and infections. Advances in Internal Medicine 9:45-80.

Kind L S, 1953 Inhibition of histamine death in pertussis inoculated mice by cortisone and neoantergan. Journal of Allergy 24:52-59.

Miller C L, Fletcher W B 1976 Severity of notified whooping cough. British Medical Journal 1:117-119.

Munoz J 1971 Protein toxins from Bordetella pertussis. In: Kadis S, Montie T C, Ajl S J (eds) Microbial toxins, vol IIa, Bacterial protein toxins. Academic Press, New York, pp 271-300.

Olson L C 1975 Pertussis. Medicine 54:427-469.

Perkins F T, Sheffield F W, Outschoorn A S, Hemsley D A 1973 An international collaborative study on the measurement of the opacity of bacterial suspensions. Journal of Biological Standardization 1:1-10.

Pittman M 1970 Bordetella pertussis: Bacterial and host factors in the pathogenesis and prevention of whooping cough. In: Mudd S (ed) Infectious agents and host reactions. W B Saunders Co., Philadelphia, pp 239-270.

Pittman M 1979 Pertussis toxin: The cause of the harmful effects and prolonged immunity of whooping cough. A hypothesis. Reviews of Infectious Diseases 1:401-412.

Sultzer B M 1972 Genetic control of host responses to endotoxin. Infection and Immunity 5:107-113.

Thompson H, McCandlish I A P, Wright N G 1976 Experimental respiratory disease in dogs due to Bordetella bronchiseptica. Research in Veterinary Science 20:16-23.

Wardlaw A C, Parton R 1982 Bordetella pertussis toxins. Pharmacology and Therapeutics 19:1-53.

Wardlaw A C, Parton R 1983 Pertussis vaccine. In: Easmon C S F, Jeljaszewicz J (eds) Medical microbiology, vol. 2. Immunization against bacterial disease. Academic Press, London, pp 207-253.

Wardlaw A C, Parton R, Hooker M J 1976 Loss of protective antigen, histamine-sensitising factor and envelope polypeptides in cultural variants of Bordetella pertussis. Journal of Medical Microbiology 9:89-100.

Zoumboulakis D, Anagnostakis D, Albanis V, Matsaniotis N 1973 Steroids in treatment of pertussis: a controlled clinical trial. Archives of Disease in Childhood 48:51-54. 